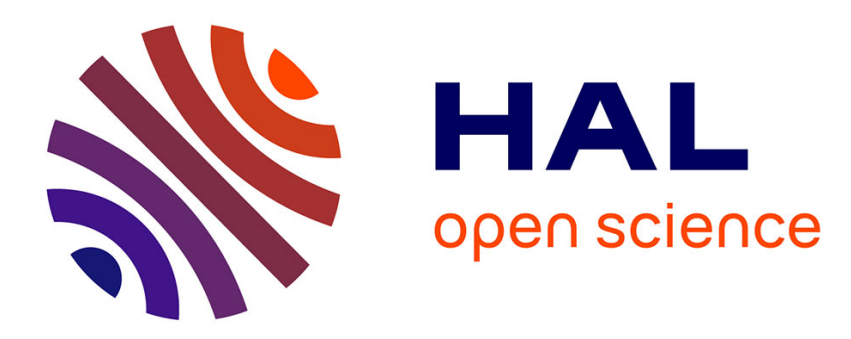

\title{
Deformation mechanisms of salt under repository conditions
}

\author{
F.D. Hansen
}

\section{To cite this version:}

F.D. Hansen. Deformation mechanisms of salt under repository conditions. Revue de Physique Appliquée, 1988, 23 (4), pp.711-711. 10.1051/rphysap:01988002304071100 . jpa-00245866

\section{HAL Id: jpa-00245866 https://hal.science/jpa-00245866}

Submitted on 1 Jan 1988

HAL is a multi-disciplinary open access archive for the deposit and dissemination of scientific research documents, whether they are published or not. The documents may come from teaching and research institutions in France or abroad, or from public or private research centers.
L'archive ouverte pluridisciplinaire HAL, est destinée au dépôt et à la diffusion de documents scientifiques de niveau recherche, publiés ou non, émanant des établissements d'enseignement et de recherche français ou étrangers, des laboratoires publics ou privés. 
A repository for heat-generative nuclear waste provides an engineering challenge far beyond general experience. Long-term repository performance is precluded from direct observation, and therefore must be predicted. A valid predictive model must first represent physical phenomena observed in laboratory tests; for example, the strain rate should be a function of stress difference, temperature, and structure. Deformation of salt subjected to conditions expected in a repository has been shown to be very sensitive to temperature and stress. More recent experiments show that history effects, normal transient response (where strain rate decreases), inverse transients (where strain rate increases), and dependence of creep rate on stress difference and temperature are a direct consequence of existing and evolving substructures. Therefore, a constitutive law must be more than a reasonable approximation of laboratory results, it must be hinged on the physical processes that account for deformation.

Because the physical processes depend primarily on stress and temperature, it is convenient to display and discuss each mechanism as a field in stress-temperature space. These diagrams, called deformation mechanism maps, have been compiled for a large number of crystalline materials. A deformation mechanism map for natural salt will be used as a means to discuss the various processes of plastic deformation.

Creep of natural rock salt in the laboratory under repository conditions produces consistent substructures. The substructures are studied using etched cleavage chips and an optical microscope. Generally, as stress and temperature of a test increase, the induced strain increases and the attendant substructures become better developed. The first evident substructural change (i.e., observable at low stresses, temperatures, and strains) is an increase in dislocation density. The increase over the natural density occurs at strains appreciably less than 1 percent. At slightly greater levels of strain, dislocations cluster along preferred crystallographic planes. As test conditions become more severe, particularly as temperature increases, the individual bands become wavy and cross link. At temperatures above one-third of the melting temperature and strains of a few percent, equant polygons form. Recent research has demonstrated that dynamic recrystallization may be an important mechanism at large strain. Other substructures at low stress and temperature hold the key to understanding the (thus far) unknown mechanism(s) that operates over this important range of repository conditions.
Brittle mechanisms are not considered because almost all of the samples were deformed at a confining pressure of $15 \mathrm{MPa}$, which is sufficient to suppress fracture. The documented plastic deformational processes, phenomenology, substructures, and constitutive models will be presented in the poster session. An increase in dislocation density is consistent with the observed phenomenology, (i.e., hardening) but the process has not been used in a constitutive equation. Glide as a mechanism has been directly incorporated into mechanism-based constitutive models. Cross slip may be a very important mechanism because wavy glide bands are observed in many samples deformed between room temperature and $100^{\circ} \mathrm{C}$. Wawersik and Zeuch [1] and Wawersik [2] have fit a cross slip model to several sets of experimental data. Their results suggest cross slip may control creep of salt at low temperatures and stresses. The diffusion-controlled processes are incorporated directly into mechanistic constitutive models. Recovery by climb which results in polygonized subgrain arrays has been documented by much observational work [3]. The associated activation energies inferred from 1 aboratory experiments over the repository range of temperatures are, however, much lower than an activation energy for diffusion of $\mathrm{Cl}^{-}$. Finally, recrystallization has been observed in salt deformed in creep experiments to high strain and in relaxation experiments [4].

\section{REFERENCES}

[1] Wawersik, W. R. and D. H. Zeuch, 1984. Creep and Creep Modeling of Three Domal Salts--A Comprehensive Update, SAND84-0568, Sandia National Laboratories, Albuquerque, NM.

[2] Wawersik, W. R., 1984. "Alternatives to a Power-Law Creep Model for Rock Salt at Temperatures Below $160^{\circ} \mathrm{C}, "$ Proceedings of the Second Conference on Mechanical Behavior of Salt, H. R. Hardy, Jr. and M. Langer, eds., Hannover, Germany, September, pp. 1-26.

[3] Carter, N. L. and F. D. Hansen, 1983. "Creep of Rocksalt," Tectonophysics, Vol. 92, pp. 275-333.

[4] Urai, J. L., C. J. Spiers, H. J. Zwart, and G. S. Lister, 1986. "Weakening of Rock Salt by Water During Long-Term Creep," Nature, Vo1. 324, pp. 554-557. 